\title{
Do Bank Size Moderate Relationship between Banks' Portfolio Diversification and Financial Performance of Commercial Banks in Kenya?
}

\author{
Stephen Githaiga Ngware*1(D), Tobias Olweny ${ }^{2}$; Willy Muturi ${ }^{3}$ \\ 1,2,3 Jomo Kenyatta University of Agriculture and Technology, Kenya \\ * Corresponding author: sngithaiga@yahoo.com
}

\begin{abstract}
Article History
Received 2019-11-22

Revised 2020-01-12

Accepted 2020-02-09

Published 2020-02-18
\end{abstract}

\section{Keywords}

Portfolio Diversification

Dynamic Panel Model

Fixed Effects

Sectoral credit

Investment portfolio

Income streams

\section{How to cite?}

Ngware, S. G., Olweny, T., \& Muturi, W. (2020). Do Bank Size Moderate

Relationship between Banks' Portfolio

Diversification and Financial Performance

of Commercial Banks in Kenya?

SEISENSE Journal of Managment,

3(2), 14-30. doi:

10.33215/sjom.v3i2.261
Purpose- It is complicated to efficiently manage the bank's portfolio, simultaneously maximize returns and minimize risks while being subject to managerial and regulatory constraints. In the financial industry, the size of a bank is used to assist in capturing economies as well as diseconomies of scale.

Design/Methodology- As in cases of most literature from finance, natural logarithms of banks' total assets were made use of to measure commercial banks' size. The 43 commercial banking institutions having an official license from CBK by December 2017 were the target population of this study. The study analyzed TimeSeries Cross-Sectional unbalanced secondary panel data obtained from all the 43 commercial banking institutions in Kenya for fifteen years ranging from 2003 to 2017.

Findings- Study findings revealed a positive effect of bank size on $\mathrm{ROE}$ and ROA that was significant. Correlation analysis revealed a positive association of bank size on the financial performance of banks in Kenya, which was significant. Bank size had a significant moderating effect on the relationship of banks portfolio diversification and financial performance of banks in Kenya.

Practical Implications- The findings on bank size insinuated that a higher size of entire asset of banks is most probable to accelerate the bank to diversify into feasible opportunities on investment, traverse more enhanced lines of business, increase capacity in market power and, produce increased value that boosts the firm to profit from economies of scale and wider scope and henceforth superior and increased financial performance. 


\section{Introduction}

Institutions of Commercial Banking, similarly to many others for profit-making institutions, are anticipated to generate revenues profitably through efficient, effective portfolio utilization of available capital resources to make certain of progression and delivering on the expectations by the shareholders of maximum returns on their investments. Financial intermediation is the core role of commercial banks to a large extent can be defined as receipt of funds from units with surpluses in the form of varying deposit accounts to extend units experiencing deficit through lending and advances at distinct prices. Banks in their mandate of performing their core functions of intermediation should be aligned to the circle of development economically and socially of a nation. At this era of economic challenges and reforms, banks are facing a critical time of distress. There is a need to put in place strategies to help savage the banking system. It is, therefore, imperative to strengthen the portfolio mix of the banks.

Olarewaju, Migiro, and Sibanda (2018) concurred with other authors' theoretical prescriptions among them (Kazan \& Uludag, 2014; Markowitz, 1952; Meressa, 2017)by stating that all these diversification avenues such as sectoral credit, assets, deposit types, and income streams are avenues in banks to make use of to be able to exploit new viable ventures to add to their intermediation services that are regarded as traditional to accrue market power and as well withstanding stringent growing competition. Empirical literature on size of bank dated back to 1984 where it was stated that sizeable firms are seen to be extra efficient and profitable than in the case of smaller firms as a result of their superiority in terms of efficiency as outlined by the hypothesis of relative efficiency (Clarke, Davies, \& Waterson, 1984). Fama and French (2005) apprehended much of the across sections average stocks returns by suggesting from a firm's perspective, that firms with smaller size face a higher cost of capital as opposed to sizeable firms.

The study by Markowitz (1959) discussed how to pursue quantification of risk and also exhibited quantitatively in what way and manner diversification in a portfolio can work to reduce investor's risk exposure. Exposure in a portfolio is quantitatively described as the standard deviation of expected yield from a period to the next, and the portfolio acquisition challenge is minimized to composing an 'efficient' portfolio, whereby it heavily brings down the exposure for a particular level of gain in a period. In the financial industry, the size of a bank is used to assist in capturing economies as well as diseconomies of scale. As in cases of most literature from finance, the natural logarithm of banks' total assets is made use of to measure commercial banks' size. The size was also included in the regression model for purposes of taking in to account for prospective nonlinearities arising from diseconomies of scale as banking firms become bigger.

An important question underlying policy on financial institutions at what point do size optimizes efficiency. Regulators in the financial sector have continued to lay emphasis on the size of the players by prescribing the minimum capital base. It is regarded as likely growing in size, and stability is enhanced. Intuitively, it is expected that a relationship that is positive will arise from the knowledge that bigger commercial banks can build material, human, financial, and technical resources, thus promoting their efficiency level. In a divergent direction, since agency problem, dysfunction as well as coordination, are more inherent in bigger firms, the expectation will be that smaller banks inculcate inefficiency scores that are lower than of bigger firms (Karray \& Chichti, 2013).

Kenyan banking system composition sums up to a total of 40 banks from the existing 42 as I\&M Holdings has concluded the purchase of Giro Commercial Bank and Diamond Trust Bank, Kenya is currently in the process of Habib Bank Limited Kenya acquisition. Banks that are under receivership include Chase Bank and Imperial Bank. One mortgage finance firm, twelve licensed microfinance banks, eight offices representing foreign banks, eighty-six bureaus of foreign exchange, fourteen providers of services of money remittance, and three credit reference bureaus. In Kenya, Financial inclusion is continuously surging, considering that the population living within 3 kilometers of an access point of financial services rose to an average of $77.0 \%$ in 2016 from $59 \%$ year 
average in 2013. This has been accelerated by digital banking, Mobile Financial Services (MFS) emerging as the method preferred in accessing financial services in 2016 (CBK, 2016).

Annual financial report by CBK (2016) highlighted that banks in Kenya registered growth in EPS that was anemic in $2016 \mathrm{FY}^{\prime}$ at 4.4\%, and FY'2015 at 2.8\%, compared to 13.9\% 5-year average. This poor performance resulted from sector's structural challenges specifically on non-performing loans provisioning, shrinking growth in private sector credit, deposit, and liquidity challenges. It is imperative to scrutinize the input-output mix that comprises the portfolio basket of these banking institutions and the manner they have interlinked amongst them to ascertain the individual aggregated levels of performance. The study has ground to be of significance since it will aid the regulatory agencies and institutions in activities of monitoring of the banks and prerequisite stakeholders in the optimization of management objective that is formal in maximizing returns. Consequently, the study sought to scrutinize whether bank size does moderate the relationship between Bank Portfolio diversification (sectoral credit, income streams, deposits, and investment diversification) and financial performance of commercial banks in Kenya.

\section{Literature Review}

The Market-Power hypothesis explains that the outcome emanating from growth in size on the profitability of an institution seems significant and largely positive (Athanasoglou, Brissimis, \& Delis, 2008). Sizeable firms are seen to be extra efficient and profitable than in the case of smaller firms as a result of their superiority in terms of efficiency, as outlined by the hypothesis of relative efficiency (Clarke et al., 1984). Expanding the size of the firm may, in consequence, cause separation of control from ownership if the size reaches a threshold. The association existing between the size of an organization and profitability can turn to retrogressive afar from the threshold size of the firm. Fama and French (2005) apprehended much of the across sections average stocks returns by suggesting from a firm's perspective, that firms smaller face higher cost of capital as opposed to sizeable firms.

This paper was grounded on Modern Portfolio Theory (MPT) that was originated from work done by (Markowitz, 1952, 1959). The financial sector has practically applied MPT to a greater extent. MPT mathematically is a construct of diversification idea in investing, whereby the main purpose is to ensure that investors can succeed in negating investment assets that have jointly lowest risks than a sole asset. Given that this is achievable, it can be perceived intuitively since assets that are not similar and often exhibit value change in the opposite manner. An investor needs to make an approximation of anticipated returns and variance or risk that may be attributable to every portfolio of assets and then choose the one which has is more viable based on the parameters (Athanasoglou et al., 2008).

MPT was used to anchor this study because of its applicability to scrutinizing diversification and financial performance. MPT theory acknowledges diversification as very important for risk mitigation and increasing returns that are expected. The theory advocates for mathematically evaluating portfolio diversification to maximize returns. According to MPT theory, spreading investments throughout stocks that are not in a way related can lead to maximization of the firm's potential revenues irrespective of whether there is economic growth or not. Scholars have put across that the asset class allocation across various markets with the independence of liquidity minimize the effect of risk that is diversifiable as a result of contingencies from exterior factors one and all of the different markets (Lewellen \& Lewellen, 2010). Diversification, therefore, assists in the reduction of firms' vulnerability to exposures. Pils (2009) suggested that more diversified firms reap higher gearing and debt volume hence improve their financial performance.

In comparison with other Economies in East Africa, the banking sector in Kenya has been applauded for its diversification as well as its size. Portfolio allocation is seen to be drifting to favoring assets that are less risky such as government securities and liquid cash. By September 2016, it was recorded that government securities 
contribution was at $24 \%$ of the sector balance sheet in comparison to about $18 \%$ year average from 2011 to 2015. Private credit to GDP, which is the accepted financial development index was estimated at $34.9 \%$ in 2015 , in comparison to 45\% average for countries in Africa Sub-Sahara (CBK, 2016).

Banks' portfolio of deposits types and sectoral credit, if not carefully managed, will make it challenging in the realization of expected performance. Portfolio, in this regard, attributes to mix of deposits in the form of term structure and associated costs while portfolio mix of sectoral credits allocated is by term structure and rates applied to lend. The composition of these portfolios may translate into risks to banks, and these risks consequently affect performance. The portfolio is normally synonymous with diversification since it explains ways applied in the management of factors of unsystematic risk that are inherent in the type of operations undertaken by banks (Ndungu \& Muturi, 2019; Raphael, 2013).

The stochastic frontier approach was utilized in an analysis that compared efficiency about profit and inefficiencies in the cost of banking firms that was in operation in 29 countries in Africa sub-Sahara for the period 2000-07. Tobit regression was used to quantify the influence of environmental variables on the efficiency of commercial banking firms. The outcome indicated thanks banks that are foreign-owned were more efficient in terms of profit compared to domestic banks. It was established banks smaller in size are more efficient in their profit-making. Medium or relatively larger banking firms tend to be more efficient in cost (Kiyota, 2011).

Nodeh, Anuar, Ramakrishnan, and Raftnia (2015) did a study that the main objective was to empirically investigate the relationship of determinants of the structure of boards of management and performance of banks. The author went further to scrutinize the importance of the role played by bank size as the moderator variable on the link between independence and size of the board with the performance of the institutions. The population of thirty-seven commercial banks in Malaysia that included twenty-one conventional and sixteen Islamic banks from 2005 to 2014 were covered. Panel data analysis was used, and models of OLS and fixed effect showed that independence, as well as the size of board, depicted an impact that was positive on firms' performance. The size of banks had a moderating impact that was positive on the relationship subsisting between the determinants of structures of board and firms' financial performance.

Hanafi Tumin and Mohd Said (2010) research study was an investigation on the performance and financial ratios of banking institutions that are commercial in countries, namely China and Malaysia. Specific objectives investigated the impact of factors that were specific to a bank, among them credit, liquidity, operational expenses, capital, and the size of banking firms on how they perform in terms of profitability. The standard performance measure used as the indicator included return on average equity and returned on the average asset. Secondary data was extracted from the financial statement of banking firms that were commercial in Malaysia and China. The financial statement reports were drawn out from the database called BankScope for the duration between 2001 and 2007. The investigation was founded on data that was panel and model of a fixed effect that incorporated a balanced series of yearly data. The size of banks was estimated using real assets and squared real assets in logarithmic form. Deductions from the study indicated that the size and level of liquidity in banks don't bear any influence that is significant on how banks perform in the two countries.

Al Karim and Alam (2013) sought to assess whether the size of a bank, asset management, risk of giving credit, and efficiency of operations do have an impact that is significant on performance measures that are internally based, such as return on asset of commercial banks in Bangladeshi. A performance measure used was based on the market as indicated by the Q model by Tobin that is Price to Book ratio, performance indicators that were indicated by internal based measures such as Return on Assets, and performance measures that were based on economy measured using an index of Economic Value. Yearly time series data between the years 2008 and 2012 of banks selected extracted from audited financial reports on an annual basis were adopted and multiple regression analysis used to assess the impact of independent variables and to come up with a good-fit model 
that will assist predict the subsequent commercial banks' financial performance. It was found that the size of the bank, risks from the credit, and efficiency in operations and how assets are managed do significantly and positively affect how banking firms in Bangladeshi perform.

The impact of diversification of investment on commercial banks' financial performance in the context of Kenya was studied by (Kipleting, 2016). The design employed in this research was exploratory. The entire population of this study was derived from the commercial banks that were operation in Kenya and were in total forty. The researcher made use of data collection sheets to collect data that was secondary and was the main tool for data collection and also employed schedules for an interview for collecting data that was primary. The tools were guided by the specified intents of the study. After in-depth analysis using explanatory, inferential statistics and multiple regressions, the study made conclusions that a majority of banking institutions, along the years had in tandem adopted insurance investment, government securities, shares from exchanges, as well as bonds to enhance their profitability and subsequently better returns to their shareholders. Olarewaju et al. (2018) did scrutiny on the impact of operational diversification on banking performance using the pooled, FEM, REM, and System GMM for a duration ranging from 2006 to 2015 and were across two hundred and fifty commercial banks from 30 nations in the region of Sub-Saharan Africa. As a result of strength of robustness of SYS-GMM, it was revealed in the outcome of this assessment that using Herfindahl Hirschman index, every component relating to operational diversification that included; deposit, revenue, asset, liability, and deposit inclusive of control variables like bank size, ratios of liquidity, loan-loss ratio, cost-income ratio and the lagged return on average asset were deemed significant at 1\% level having only deposit diversification (HHIde), which had a negative link with ROAA. This assessment, however, concluded that diversification of activities relating to the operation of banks in the region of SSA has a direct effect as well as significant on financial performances. It was noted that greater attention should be taken in monitoring the diversification strategies, especially on deposits, to guarantee that no aspect of banks' operation is disregarded.

Nisar, Peng, Wang, and Ashraf (2018) paper was done as a precursor to the continuing debate on the gains and shortcomings of diversifying streams of revenue by banks. Scrutinizing a panel set of information comprising 200 commercial banks domiciled at countries in South Asia, it was discovered that generally, diversification of revenue into non-interest stream positively impacts profitability and likewise stability of commercial banks domiciled at countries in South Asia. Further, diverse forms of non-interest stream-generating undertakings possess divergent impacts on bank performance and thereby impacting their stability. It was noted that as fees and commission streams had an impact that was negative on profitability and solidity of commercial banks domiciled at countries in South Asia, other non-interest streams had positive results. The study observed that the size plays a bigger role in solidifying the financial performance of smaller and larger banks.

In general terms, the relationship that exists between bank size of banks that are commercial, and their performance is considered to be positive (Kiyota, 2011; Nodeh et al., 2015). However, several research studies have implicated bank size impact to be non-linear with profitability surging with commercial bank size and shrinking as a result of bureaucratic, among other reasons (Hanafi Tumin \& Mohd Said, 2010). Taking into consideration the above studies, Nodeh et al. (2015) findings are different from the suggested findings and conclusions by Al Karim and Alam (2013); hence the researcher is obliged to investigate further the moderation effect of the bank size.

\section{Research Methodology}

The design employed in the research was a correlation, and secondary data was gathered from statements of finance prepared annually by commercial banking institutions in Kenya. Panel data collected was scrutinized using descriptive statistics, regression, and correlation analysis. Study findings were tabulated in the form of tables and figures. The time variable in years is included to control for cycles that occurred in the economy. The dynamic panel, also called lagged regression models, was employed to control for the time lags. Immediate 
previous period performance controlled the relationship that subsisted between portfolio diversification and current period performance.

\section{Independent Variables $\quad$ Moderating Variable $\quad$ Dependent Variable}

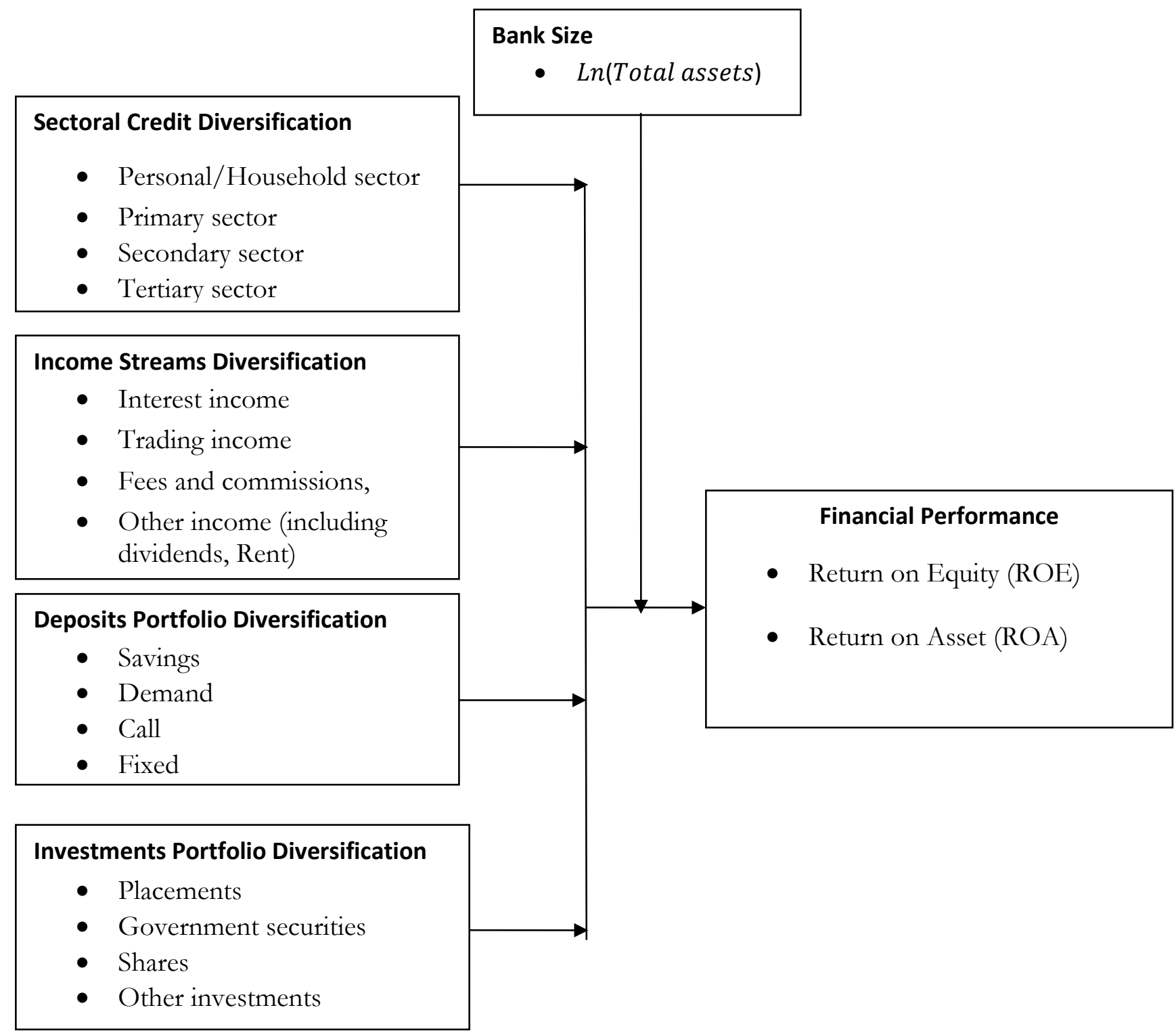

Figure 1 - Conceptual Framework

The study approximated both long run/static and short-run/dynamic panel models as specified in statistical panel models equations above. Specified long-run models were estimated by the aid of the random or fixedeffects models, and the short-run models were estimated by the aid of the system generalized method of moments estimator (Verbeek, 2008).

A general Panel regression model accommodating all the variables that explain Banks' portfolio diversification and the independent variables obtained from that place, the study can, therefore, adopt a model following the work of (Berger, Hasan, Korhonen, \& Zhou, 2010). The model is reliant on calculated figures of ROA, ROE, and HHI values of independent variables of each bank for the period 2003-2017. 


\section{Diversification Measure}

To measure the scale of diversification, the author used the Herfindahl Index. Acharya, Hasan, \& Saunders (2006) defined this indicator as to the summation of squares of individual exposure as a fraction of sum exposures under a set categorization. Herfindahl index will be preconceived as the summation of squares of a portfolio as a percentage of the square of the entire portfolio (Choi, 2001).

\section{Diversification Scale}

The following diversification scale was adopted in this study to judge the values of the Herfindahl Index (HHI), as captured in the below table:

Table 1 - Scale of Diversification

\begin{tabular}{lll}
\hline & Value of HHI & \\
\hline From & To & Conclusion \\
$\mathbf{1}$ & 0.76 & Highly concentrated \\
$\mathbf{0 . 7 5}$ & 0.51 & Lowly diversified \\
$\mathbf{0 . 5}$ & 0.26 & Diversified \\
$\mathbf{0 . 2 5}$ & 0 & Highly diversified \\
\hline
\end{tabular}

(Source: (Acharya, Hasan, \& Saunders, 2006))

Awang, (2012) analysis methodology to assess bank size moderation on the relationship between bank portfolio diversification and performance of banks was used. Assuming a multiplicative functional form between explanatory and explained variables by introducing bank size as a moderator;

Linearized and parameterized long-run models (Fixed or Random effect) were as shown in equations 3.10a and $3.10 \mathrm{~b}$

$R O E_{\mathrm{i}, \mathrm{t}}=\beta_{0}+\sum_{j=1}^{4} \beta_{j} X_{i, t}+\beta_{q} M_{i, t}+\sum_{j=5}^{8} \beta_{j} X_{i, t} \mathrm{M}_{i, t}+\alpha_{i, t}+\varepsilon_{i, t}$

$R O A_{\mathrm{i}, \mathrm{t}}=\beta_{0}+\sum_{j=1}^{4} \beta_{j} X_{i, t}+\beta_{q} M_{i, t}+\sum_{j=5}^{8} \beta_{j} X_{i, t} \mathrm{M}_{i, t}+\alpha_{i, t}+\varepsilon_{i, t}$

Linearized and parameterized short-run models (GMM) were as specified in 3.10c and 3.10d

$R O E_{\mathrm{i}, \mathrm{t}}=\beta_{0}+\lambda R O E_{\mathrm{i}, \mathrm{t}-1}+\sum_{j=1}^{4} \beta_{j} X_{i, t}+\beta_{q} M_{i, t}+\sum_{j=5}^{8} \beta_{j} X_{i, t} \mathrm{M}_{i, t}+\alpha_{i, t}+\varepsilon_{i, t}$
$R O A_{i, t}=\beta_{0}+\lambda R O E_{i, t-1}+\sum_{j=1}^{4} \beta_{j} X_{i, t}+\beta_{q} M_{i, t}+\sum_{j=5}^{8} \beta_{j} X_{i, t} M_{i, t}+\alpha_{i, t}+\varepsilon_{i, t}$

The test of moderation is operationalized by the product term XitMit the multiplication between independent variable Xit and moderator variable $\mathrm{M}$. For testing moderation in the model, and there was a need to test $\beta 5-$ $\beta 8$ which was the coefficient of interaction term XitMit. If $\beta 5-\beta 8$ were significant, the conclusion was that moderator variable bank size moderates relationship subsisting between banks' portfolio diversification, Xit, and financial performance, Yit. If $=1$, bank size is large, otherwise is zero. Mi,t is bank size measured by the natural logarithm of total assets of a bank at time t. 


\section{Results}

\section{Descriptive Statistics}

None of the bank's portfolio diversification was normally since their respective Jarque-Berra coefficients were less than 0.05 . The average bank size was 9.86, with a minimum of 2.23 and a maximum of 14.86 . There were lean variations on commercial bank size, as stipulated by a standard deviation of 1.51. Kurtosis was lowest at 2.33 and highest at 13.86. This indicated that every component's kurtosis was not symmetric as that of normal distribution. Moreover, elements of the error term were either more or less peaked than that exhibited by a normal distribution. As depicted in the table, all the variables exhibited kurtosis of leptokurtic nature in nature for a reason being al the indexes of the kurtosis coefficient were all positive.

The values of probability were 0.000 amongst all the components in the series showing model made use of in the study was a good fit, and there was an expectation that every variable measured was anticipated to significantly have an impact on the financial performance of Kenyan banking industry.

Table 2 - Descriptive Statistics

\begin{tabular}{lccccccc}
\hline & ROE & ROA & SCD & HHI & HHI & HHI & DPD \\
Mean & 16.27 & 2.00 & 0.63 & 0.67 & 0.65 & 0.66 & 9.86 \\
Median & 17.19 & 2.49 & 0.70 & 0.69 & 0.71 & 0.73 & 9.66 \\
Maximum & 49.40 & 7.70 & 0.96 & 0.93 & 0.96 & 0.92 & 14.86 \\
Minimum & -26.20 & -17.00 & 0.10 & 0.29 & 0.26 & 0.25 & 2.23 \\
Std. Dev. & 14.71 & 3.52 & 0.20 & 0.16 & 0.16 & 0.16 & 1.51 \\
Skewness & -0.56 & -2.73 & -0.73 & -0.52 & -0.75 & -0.75 & -0.30 \\
Kurtosis & 3.11 & 13.86 & 2.33 & 2.42 & 2.50 & 2.37 & 5.32 \\
Jarque-Bera & 30.80 & 3531.84 & 62.48 & 33.58 & 59.97 & 63.81 & 138.15 \\
Probability & 0.00 & 0.00 & 0.00 & 0.00 & 0.00 & 0.00 & 0.00 \\
Sum & 9338.83 & 1150.31 & 362.93 & 385.97 & 374.41 & 376.40 & 5661.34 \\
Sum Sq. Dev. & 124064.40 & 7084.77 & 22.40 & 14.10 & 15.32 & 15.56 & 1311.88 \\
Observations & 574 & 574 & 574 & 574 & 574 & 574 & 574 \\
\hline
\end{tabular}

\section{Panel Hausman Test for Model with Moderation}

As captured in Table 3, the p-value was 0.000 , which was less than 0.05 . This denoted that there existed sufficient evidence to permit the non-adoption of $\mathrm{H} 0$ that we conclude that the most suited model to fit was the FE model. Consequently, the FE regression model was adopted to examine bank size moderation on the subsisting effect of banking portfolio diversification on ROE and ROA of banks in Kenya.

Table 3 - Panel Hausman Test for Model with Moderation

\begin{tabular}{llcccc}
\hline $\begin{array}{l}\text { Dependent } \\
\text { variable }\end{array}$ & Test Summary & & Chi-Sq. Statistic & Chi-Sq. d.f. & Prob. \\
\hline ROE & Variable & Fixed & Random & Var (Diff.) & Prob. \\
& HHI SCD & 17.114 & 12.595 & 19.663 & 0.308 \\
& HHI ISD & 30.470 & 7.831 & 24.020 & 0.000 \\
& HHI DPD & 8.799 & 23.297 & -32.485 & 0.011 \\
& HHI IPD & 49.241 & 52.147 & -16.940 & 0.480 \\
& Bank size & 3.720 & 2.495 & -0.241 & 0.013 \\
& HHI SCD $*$ BS & 3.569 & 3.379 & -0.184 & 0.658 \\
& HHI ISD*BS & 2.957 & 4.578 & -0.336 & 0.005 \\
\hline
\end{tabular}




\begin{tabular}{llcccc}
\hline \hline & HHI DPD*BS & 4.083 & 1.980 & 0.208 & 0.000 \\
& HHI IPD*BS & 3.583 & 3.599 & -0.176 & 0.970 \\
\hline ROA & Test Summary & & Chi-Sq. Statistic & Chi-Sq. d.f. & Prob. \\
& & 19.278 & 9 & 0.023 \\
& Variable & Fixed & Random & Var (Diff.) & Prob. \\
& HHI SCD & 9.616 & 10.560 & -0.665 & 0.247 \\
& HHI ISD & 7.642 & 10.795 & -0.880 & 0.001 \\
& HHI DPD & 5.096 & 6.229 & -1.160 & 0.293 \\
& HHI IPD & 8.571 & 9.680 & -0.576 & 0.144 \\
Bank size & 1.043 & 1.277 & -0.009 & 0.011 \\
& HHI SCD * BS & 0.539 & 0.623 & -0.006 & 0.286 \\
& HHI ISD*BS & 0.842 & 0.955 & -0.012 & 0.304 \\
& HHI DPD*BS & 0.652 & 0.917 & -0.008 & 0.002 \\
& HHI IPD*BS & 0.641 & 0.723 & -0.006 & 0.291 \\
\hline
\end{tabular}

\section{Hypothesis Testing}

Regression results in Table 4 revealed that 81.58 percent of changes in ROE was accounted for by bank portfolio diversification, bank size, and moderated bank portfolio while the remaining percentage was as a result of other factors excluded in the derived model. $\mathrm{R}$ squared was very strong after moderation, which indicated banking size had a moderating effect on the subsisting effect of banks' portfolio diversification on the financial performance of commercial banks in Kenya. Further, bank size had a significant positive effect on banking performance in Kenya $(\beta=3.7204$, p-value $<0.05)$.

After bank size moderation on HHI SCD*BS, it had a positively significant effect on ROE $(\beta=3.5691$, $p$-value $<0.05)$. Secondly, there a positive and non-significant moderated effect of HHI ISD*BS $(\beta=2.9571, \mathrm{p}$-value $>0.05)$. Thirdly, there was a positively significant moderated effect of HHI DPD*BS $(\beta=4.0829, \mathrm{p}$-value $<0.05)$. Finally, there was a positively significant moderated effect of HHI IPD*BS $(\beta=3.5826$, p-value $<0.05)$.

ROE $=-11.8427+17.1142 *$ HHI SCD $+30.4703 *$ HHI ISD $+8.7986 *$ HHI DPD + 49.2408* HHI IPD + $3.7204 *$ Bank size $+3.5691 * \mathrm{HHI}$ SCD $* \mathrm{BS}+2.9571 * \mathrm{HHI}$ ISD $* \mathrm{BS}+4.0829 * \mathrm{HHI} \mathrm{DPD} * \mathrm{BS}+3.5826 * \mathrm{HHI}$ IPD*BS.

Bank size moderating effect was confirmed through comparison of moderated and non-moderated coefficients with marginal changes of bank size on association of banking portfolio diversification and financial performance of banks in Kenya. Bank size moderation effect will be present if marginalized coefficients will differ from non-moderated banking portfolio diversification coefficients. The following equations were adopted:

$$
\begin{aligned}
& \frac{\delta R O E i, t}{\delta H H I S C D i, t}=\beta_{1}+\beta_{6} \mathrm{BS}=17.1142+3.5691 * 9.86=52.3055 \\
& \frac{\delta R O E i, t}{\delta H H I I S D i, t}=\beta_{2}+\beta_{7} \mathrm{BS}=30.4703+2.9571 * 9.86=59.6273 \\
& \frac{\delta R O E i, t}{\delta H H I D P D i, t}=\beta_{3}+\beta_{8} \mathrm{BS}=8.7986+4.0829 * 9.86=49.0560 \\
& \frac{\delta R O E i, t}{\delta H H I I P D i, t}=\beta_{4}+\beta_{9} \mathrm{BS}=49.2408+3.5826 * 9.86=84.5652
\end{aligned}
$$


Comparison between marginalized coefficients and those non-moderated in equation 4.1, these coefficients differed. Hence, it was concluded that banking institutions' size moderated significantly, the subsisting effect of banks portfolio diversification on ROE of banks in Kenya.

Table 4 - Bank Size Moderating Effect on Effect of Banks Portfolio Diversification ROE

\begin{tabular}{lcccc}
\hline Variable & Coefficient & Robust Std. Error & t-Statistic & Prob. \\
\hline C & 11.8427 & 11.3509 & 1.0433 & 0.2973 \\
HHI SCD & 17.1142 & 17.3522 & 0.9863 & 0.3244 \\
HHI ISD & 30.4703 & 15.3197 & 1.9890 & 0.0472 \\
HHI DPD & 8.7986 & 20.3085 & 0.4332 & 0.6650 \\
HHI IPD & 49.2408 & 18.8819 & 2.6078 & 0.0094 \\
Bank size & 3.7204 & 1.1916 & 3.1223 & 0.0019 \\
HHI SCD $*$ BS & 3.5691 & 1.7953 & 1.9880 & 0.0473 \\
HHI ISD*BS & 2.9571 & 2.0882 & 1.4161 & 0.1573 \\
HHI DPD*BS & 4.0829 & 1.5456 & 2.6416 & 0.0085 \\
HHI IPD*BS & 3.5826 & 1.8614 & 1.9247 & 0.0548 \\
R-squared & 0.8158 & Mean dependent var & & 16.2697 \\
Adjusted R-squared & 0.7994 & S.D. dependent var & & 14.7145 \\
S.E. of regression & 6.5911 & Akaike info criterion & & 6.6892 \\
Sum squared residuals & 22850.5700 & Schwarz criterion & & 7.0532 \\
Log-likelihood & -1871.8080 & Hannan-Quinn criterion. & & 6.8312 \\
F-statistic & 49.5713 & Durbin-Watson stat & & 1.4372 \\
Prob(F-statistic) & 0.0000 & & & \\
\hline
\end{tabular}

Regression results in Table 5 revealed that 74.66 percent of changes in ROA was accounted for by bank portfolio diversification, bank size, and moderated bank portfolio while the remaining percentage was as a result of other factors excluded in the derived model. $\mathrm{R}$ squared was very strong after moderation, which indicated banking size had a moderating effect on the effect of bank portfolio diversification on ROA of banks in Kenya. Further, bank size had a significant positive effect on banking performance (ROA) in Kenya $(\beta=1.0428$, pvalue $<0.05)$.

After bank size moderation on HHI SCD*BS it had positive and non-significant effect on ROA $(\beta=0.5393$, p-value $>0.05)$. Secondly, there a positive and non-significant moderated effect of HHI ISD*BS on ROA $(\beta=$ 0.8419 , $\mathrm{p}$-value $>0.05)$. Thirdly, there was the positive and non-significant moderated effect of HHI DPD*BS on ROA $(\beta=0.6518$, $p$-value $>0.05)$. Finally, there was a positive and non-significant moderated effect of HHI IPD*BS $(\beta=0.6410$, $\mathrm{p}$-value $>0.05)$.

ROA $=-15.3079+9.6156 *$ HHI SCD $+7.6419 *$ HHI ISD $+5.0961 *$ HHI DPD $+8.5714 *$ HHI IPD + $1.0428 *$ Bank size $+0.5393 *$ HHI SCD $*$ BS $+0.8419 *$ HHI ISD $*$ BS $+0.6518 *$ HHI DPD*BS $+0.6410 *$ HHI IPD*BS.

Bank size moderating effect was confirmed through comparison of moderated and non-moderated coefficients with marginal changes of bank size on banking portfolio diversification on financial performance (ROA). Bank size moderating effect will be present if marginalized coefficients will differ from non-moderated banking portfolio diversification coefficients. The following equations were adopted:

$\frac{\delta R O A i, t}{\delta H H I S C D i, t}=\beta_{1}+\beta_{6} \mathrm{BS}=9.6156+0.5393 * 9.86=14.9331$ 


$$
\begin{aligned}
& \frac{\delta R O A i, t}{\delta H H I I S D i, t}=\beta_{2}+\beta_{7} \mathrm{BS}=7.6419+0.8419 * 9.86=15.9430 \\
& \frac{\delta R O A i, t}{\delta H H I D P D i, t}=\beta_{3}+\beta_{8} \mathrm{BS}=5.0961+0.6518 * 9.86=11.5229 \\
& \frac{\delta R O A i, t}{\delta H H I \text { IPDi,t }}=\beta_{4}+\beta_{9} \mathrm{BS}=8.5714+0.6410 * 9.86=14.8917
\end{aligned}
$$

Comparison between marginalized coefficients and those non-moderated in equation 4.2, these coefficients differed. Hence, it was concluded that bank size had significant moderating on the effect of banks portfolio diversification on ROA of commercial banks in Kenya.

\begin{tabular}{lcccc}
\multicolumn{1}{l}{ Table 5 - Bank Size Moderating Effect on Effect of Banks Portfolio Diversification on ROA } & & \\
\hline Variable & Coefficient & Robust Std. Error & t-Statistic & Prob. \\
\hline C & -15.3079 & 3.1818 & -4.8110 & 0.0000 \\
HHI SCD & 9.6156 & 4.8641 & 1.9768 & 0.0486 \\
HHI ISD & 7.6419 & 4.2944 & 1.7795 & 0.0757 \\
HHI DPD & 5.0961 & 5.6928 & 0.8952 & 0.3711 \\
HHI IPD & 8.5714 & 5.2929 & 1.6194 & 0.1060 \\
Bank size & 1.0428 & 0.3340 & 3.1221 & 0.0019 \\
HHI SCD * BS & 0.5393 & 0.5033 & 1.0717 & 0.2844 \\
HHI ISD*BS & 0.8419 & 0.5853 & 1.4383 & 0.1509 \\
HHI DPD*BS & 0.6518 & 0.4333 & 1.5044 & 0.1331 \\
HHI IPD*BS & 0.6410 & 0.5218 & 1.2285 & 0.2198 \\
R-squared & 0.7466 & Mean dependent var & & 2.0040 \\
Adjusted R-squared & 0.7239 & S.D. dependent var & 3.5163 \\
S.E. of regression & 1.8476 & Akaike info criterion & & 4.1456 \\
Sum squared residuals & 1795.5310 & Schwarz criterion & 4.5095 \\
Log likelihood & -1141.7730 & Hannan-Quinn criterion. & & 4.2875 \\
F-statistic & 32.9676 & Durbin-Watson stat & & 1.9469 \\
Prob(F-statistic) & 0.0000 & & & \\
\hline
\end{tabular}

As outlined in Table 6, there was a significant short-run effect of banks' portfolio diversification on ROE of banks in Kenya and bank size moderating effect (Wald Chi-square $=473.84$, p-value $<0.05$ ). There was a positively significant effect of lagged return on ROE, sectoral credit diversification, income streams diversification, deposit diversification, investment portfolio diversification, bank size, and its moderating effect.

$\mathrm{ROE}=-9.5389+0.2341 * \mathrm{ROE}_{\mathrm{t}-1}-10.2806 * \mathrm{HHI} \mathrm{SCD}-20.4181 *$ HHI ISD $+46.5967 *$ HHI DPD + $22.5665 * \mathrm{HHI}$ IPD $-1.5715 *$ Bank size $+2.878 * \mathrm{HHI}$ SCD $* \mathrm{BS}+3.1173 *$ HHI ISD $* \mathrm{BS}-2.9287 * \mathrm{HHI}$ DPD*BS - $1.1575^{*} \mathrm{HHI}$ IPD*BS ..4.3

Bank size moderating effect was confirmed through comparison of moderated and non-moderated coefficients with marginal changes of bank size on banking portfolio diversification on financial performance. Bank size moderating effect will be present if marginalized coefficients will differ from non-moderated banking portfolio diversification coefficients. The following equations were adopted:

$\frac{\delta R O A i, t}{\delta H H I S C D i, t}=\beta_{1}+\beta_{6} \mathrm{BS}=-10.2806+2.878 * 9.86=18.09648$

$\frac{\delta R O A i, t}{\delta H H I I S D i, t}=\beta_{2}+\beta_{7} \mathrm{BS}=-20.4181+3.1173 * 9.86=10.318478$ 
$\frac{\delta R O A i, t}{\text { SHHI DPDi,t }}=\beta_{3}+\beta_{8} \mathrm{BS}=46.5967-2.9287 * 9.86=17.719718$

$\frac{\delta R O A i, t}{\delta H H I I P D i, t}=\beta_{4}+\beta_{9} B S=22.5665-1.1575 * 9.86=11.15355$

Comparison between marginalized coefficients and those non-moderated in equation 4.3 these coefficients differed. Hence, it was concluded that bank size had significant moderating on the effect of banks portfolio diversification on ROA of commercial banks in Kenya.

Table 6 - Dynamic Panel Model on Bank Size Moderating Effect on the Effect of Banks Portfolio Diversification on ROE

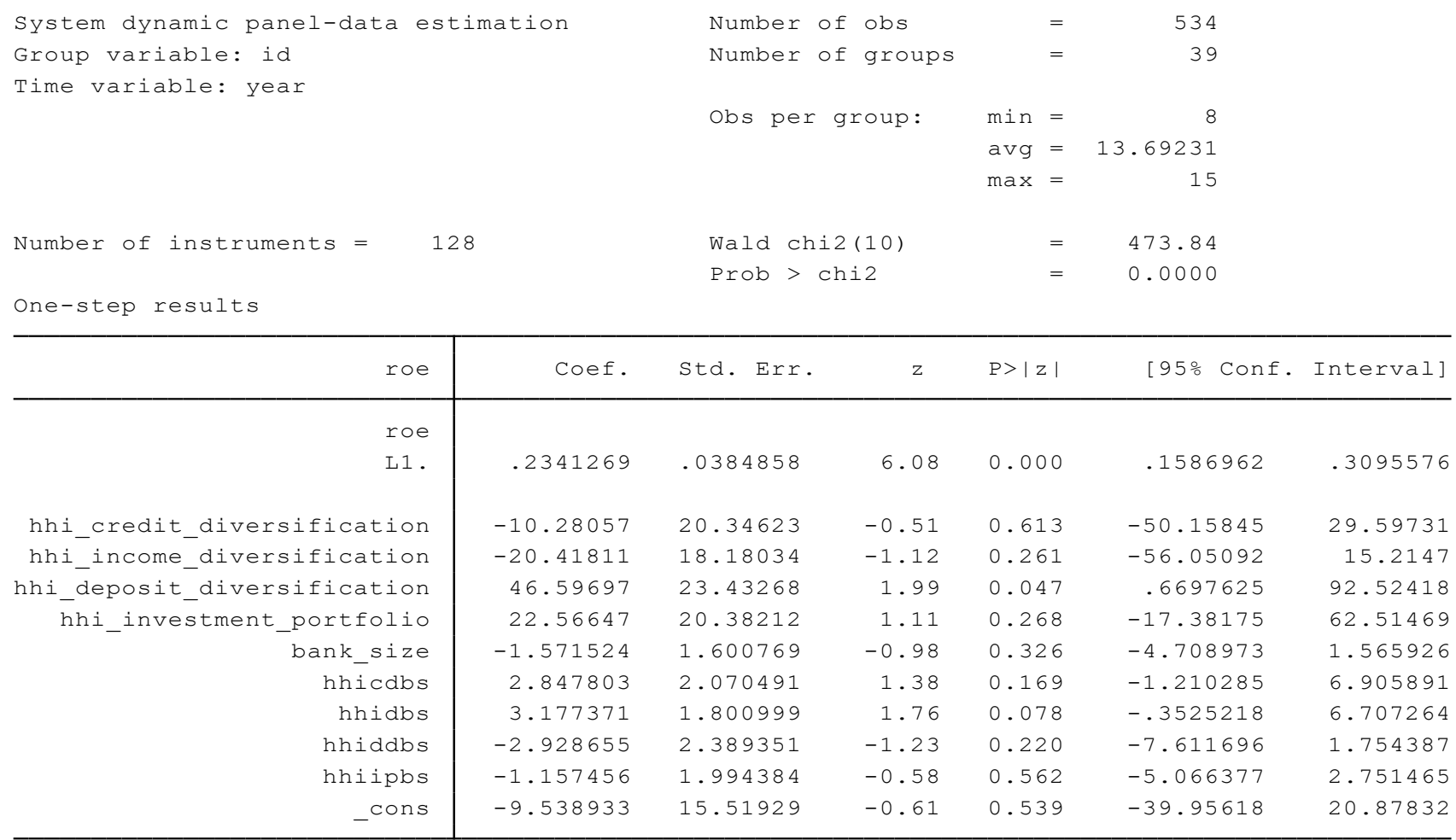

Adaption of the Sargan test in the study enabled the determination of the likelihood of the model underestimation. The $\mathrm{H} 0$ in the test outlined that the model's underlying conditions were met as opposed to an alternative of their non-satisfaction. The outcome, as highlighted in Table 7, disclosed that the model was rightly identified since its $\mathrm{p}$-value was lower than 0.05 , which was the critical value.

Table 7 - Sargan Test for the Model

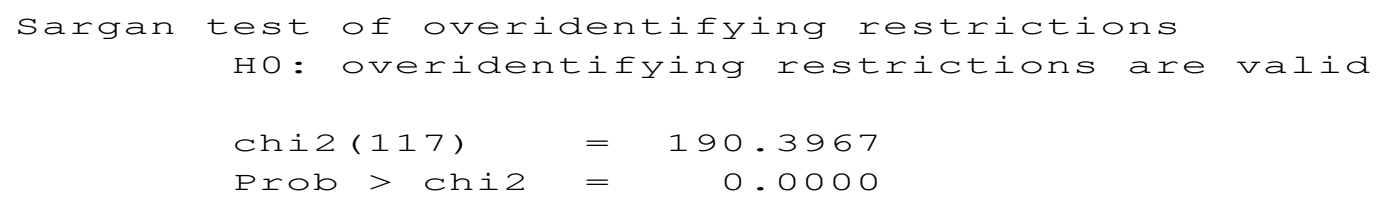

As shown in Table 8, there was a significant short-run effect of banks' portfolio diversification on ROA of banks in Kenya and bank size moderating effect (Wald Chi-square $=463.29$, p-value $<0.05$ ). There was a 
positive significant effect of lagged return on return on assets, sectoral credit diversification, income streams diversification, deposit diversification, investment portfolio diversification, bank size, and its moderating effect.

$\mathrm{ROA}=-21.6250+0.3653 * \mathrm{ROA}_{\mathrm{t}-1}+9.5979 * \mathrm{HHI} \mathrm{SCD}+7.8951 *$ HHI ISD $+7.1843 *$ HHI DPD + $10.1516 * \mathrm{HHI}$ IPD+ 1.8079* Bank size $-0.2259 * \mathrm{HHI} \mathrm{SCD} * \mathrm{BS}-0.7102 * \mathrm{HHI}$ ISD $* \mathrm{BS}-0.4719 * \mathrm{HHI}$ DPD*BS $-0.7953 *$ HHI IPD*BS ..4.4

Bank size moderating effect was confirmed through comparison of moderated and non-moderated coefficients with marginal changes of bank size on banking portfolio diversification on financial performance bottom line being all commercial banks in Kenyan context. Bank size moderating effect will be present if marginalized coefficients will differ from non-moderated banking portfolio diversification coefficients. The following equations were adopted:

$$
\begin{aligned}
& \frac{\delta R O A i, t}{\delta H H I S C D i, t}=\beta_{1}+\beta_{6} \mathrm{BS}=9.5979+-0.2259 * 9.86=7.370526 \\
& \frac{\delta R O A i, t}{\delta H H I I S D i, t}=\beta_{2}+\beta_{7} \mathrm{BS}=7.8951+-0.7102 * 9.86=0.892528 \\
& \frac{\delta R O A i, t}{\delta H H I D P D i, t}=\beta_{3}+\beta_{8} \mathrm{BS}=7.1843-0.4719 * 9.86=2.531366 \\
& \frac{\delta R O A i, t}{\delta H H I I P D i, t}=\beta_{4}+\beta_{9} \mathrm{BS}=10.1516-0.7953 * 9.86=2.309942
\end{aligned}
$$

Comparison between marginalized coefficients and those non-moderated in equation 4.4, these coefficients differed. Hence, it was concluded that bank size had significant moderating on the effect of banks portfolio diversification on ROA of banking in bottom line of Kenya.

Table 8 - Dynamic Panel Model on Bank Size Moderating Effect on the Effect of Banks Porffolio Diversification on ROA

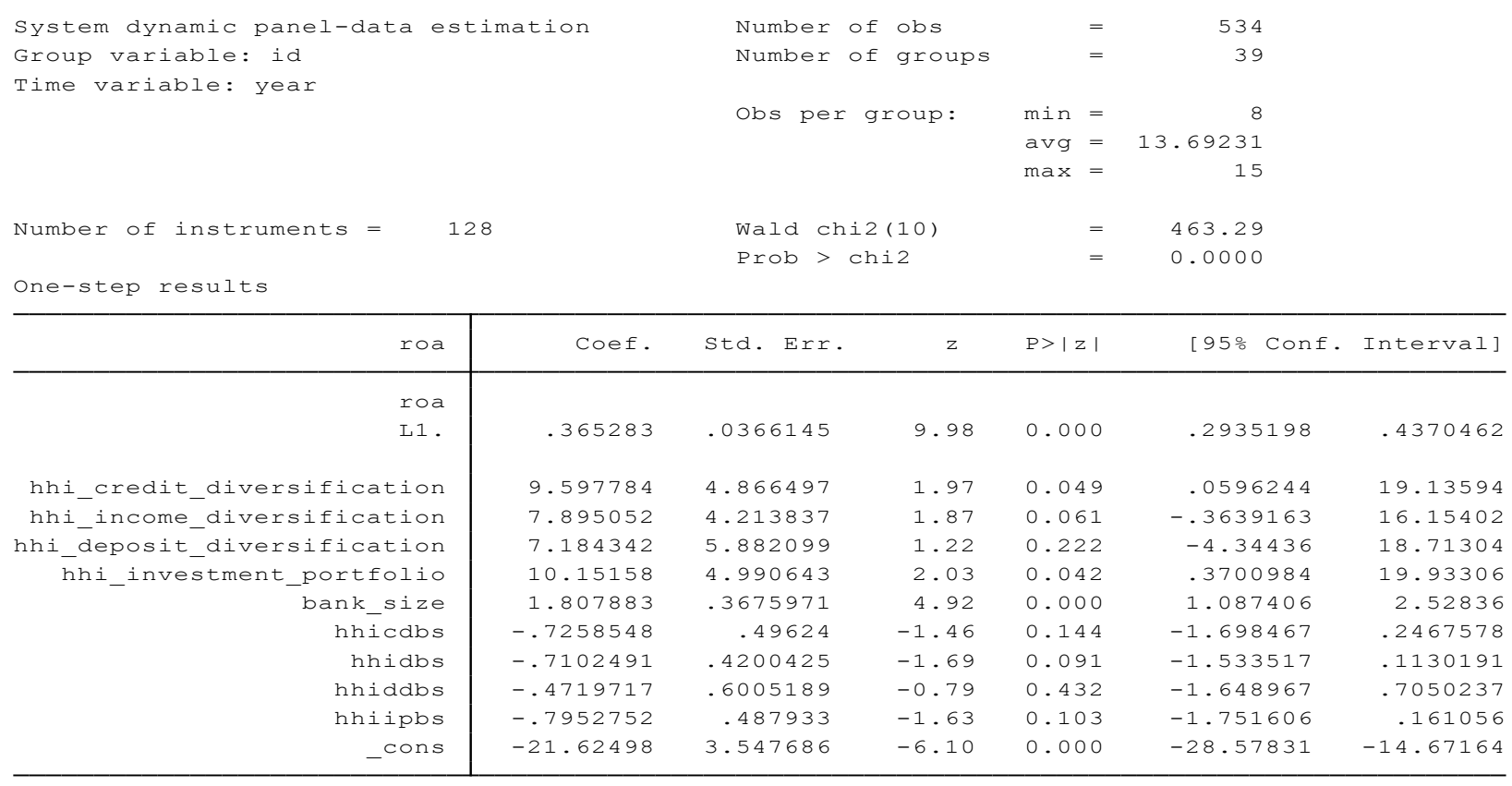


The adoption of the Sargan test was solely for the examination of the likelihood of model under-estimation. The $\mathrm{H}_{0}$ in the test outlined that the model's underlying conditions were met as opposed to an alternative of their non-satisfaction. The outcome, as highlighted in Table 9, disclosed that the model was rightly identified since its p-value was lower than 0.05 , which was the critical value.

Table 9 - Sargan Test for the Model

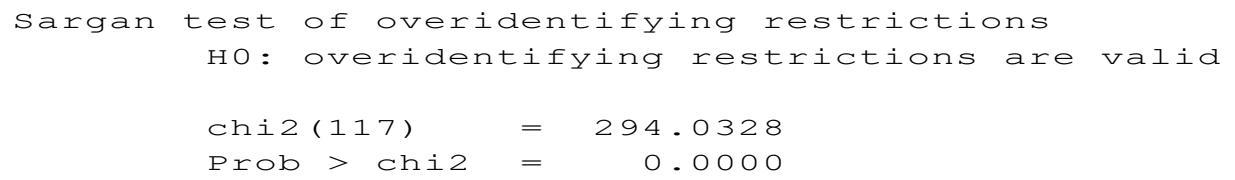

Bank size was seen to have a positive association with banking performance, which was significant $(p$ value $<0.05$ ), and this confirmed the deductions made by Stiroh (2004); Afzal and Mirza (2012); DeYoung and Rice (2004). In the two dynamic panel models with ROE and ROA representing the performance of banks, the number of instruments (128) is fairly low when it was compared to the number of observations (534), confirming that there is no problem emanating from instrument proliferation. The Sargan test that was significant $(\mathrm{p}$ value $=0.00 ;<0.05)$ shown that the instrument set was valid and more so exogenous. These results of the diagnostic tests of system GMM in the models thus validated the models and as well-validated conclusions and observations made based on system GMM estimations. The time variable in years is included to control for cycles that occurred in the economy. The number of groups of 39 represented the number of banks that were analyzed in this study. The minimum was (8) and maximum was (15) with an average of (13.69) observed groups.

The positive direction of influence in both models that is static and dynamic panel of sectoral credit, income streams, deposits types, and investment avenues diversification as well as their significance resonates to results insinuated by the study of Turkmen and Yigit (2012); Ebrahim and Hasan (2008); Mulwa, Tarus, and Kosgei (2015)where they indicated that diversification lowers systematic risk, reduces volatility in earnings and henceforth lowers agency. The findings were also in agreement with Landi and Venturelli (2001), who underlined that diversification significantly affected efficiency in terms of profits, prices, and revenue growth.

The size of the banks, in many instances, is made use of in the banking system to control for risk and cost difference. The results displayed in this study insinuates that the larger or bigger the entire assets of banks, the wider the scale of diversity into viable areas of investment, the more banks explore diverse lines of business, strengthen market power and in tandem, add value for boosting benefits derived from economies of scale and scope thereby appealing and improved performance. Diversifying portfolios by banking institutions decide degrees of risk banks are inclined to incur. Losses emanating from one portfolio can be paid back by the earnings derived from other portfolio combinations. It is henceforth of prime importance for banking institutions to mold their strategic resolutions while giving more attention to risk-return preferences controlled by bank size.

Nodeh et al. (2015) found that the size of banks had a moderating impact that was positive on the relationship between the determinants of structures of board and firms' financial performance depicting a consistent finding with the current study. Hanafi Tumin and Mohd Said (2010) deductions from the study indicated that size and level of liquidity in banks don't bear any influence that is significant on how banks perform in the two countries, which was contradictory with the findings depicted in the current study. Al Karim and Alam (2013) found out that the size of the bank, risks from the credit, and efficiency in operations and how assets are managed do 
have a significant and positive effect on how banking firms in Bangladeshi perform which was consistent with the findings depicted in the current study.

In general terms, the relationship that exists between bank size of commercial banks and their performance is considered to be positive (Kiyota, 2011; Nodeh et al., 2015). However, several research studies have implicated bank size impact to be non-linear, with profitability increasing with commercial bank size and shrinking as a result of bureaucratic factors, among other reasons (Hanafi Tumin \& Mohd Said, 2010). Taking into consideration the above studies, Hanafi Tumin and Mohd Said (2010) findings are different from the suggested findings and conclusions by Al Karim and Alam (2013) and Nodeh et al. (2015).

\section{Discussion}

The main objective of the study evaluated the moderating effect of bank size on the effect of bank portfolio diversification on financial performance in Kenya. Study findings revealed a positive and significant effect of bank size on ROE and ROA. Correlation analysis revealed a positive and significant effect of bank size on the financial performance of banks in Kenya. Bank size had a significant moderating effect on the effect of banks' portfolio diversification on the financial performance of banks in Kenya. This was documented with an $\mathrm{R}$ squared change of 1.22 percent and 1.3 percent for ROE and ROA, respectively. Bank size moderating effect was to be present if marginalized coefficients were to differ from non-moderated banking portfolio diversification coefficients. A comparison between marginalized coefficients and those non-moderated coefficients differed. Hence, it was concluded that bank size had significant moderating on the effect of bank portfolio diversification on ROA of commercial banks in Kenya. In conclusion, bank size affected moderated sectoral credit diversification, income streams diversification, deposits portfolio diversification, and investment portfolio diversification effect on banks' performance in Kenya. Although bank size had a positive moderating effect on the effect of banks' portfolio diversification on the financial performance of banks, it was not significant.

\section{Practical Implications}

The finding on bank size in this study insinuated that a higher size of entire asset of banks is most probable to accelerate the bank to diversify into feasible opportunities pertaining investment, traverse more enhanced lines of business, increase capacity in market power and for this reason, produce increased value that boosts the firm to profit from economies of scale and wider scope and henceforth superior and increased financial performance. Following Modern portfolio theory, credit, revenue streams, assets, and deposit are instruments in banking system to make use whereby they can traverse wider, newer and feasible investment scenarios in addition to the role of intermediation that is traditional to the level of having grounded market power that can hold out against competitiveness as the industry in the region is explosively competitive, but should engage training of human aspect of capital, growth, and redeployment to adequately enhance attainment in totality of the goal of diversification.

Commercial banks should develop strategies to increase their asset base. Alternative valuation approaches should be developed to ensure that depleting assets are continuously excluded from the future evaluation of commercial banks' assets. Furthermore, commercial banks should intensify the acquisition of tangible and intangible assets. Intangible assets may be acquired through the development of products for propelling competitive advantages.

The study finally recommends that banking institutions should refocus its activities to further the confidence in portfolio diversification, come up with marketing blueprints that encourage its use, and establish the best combination of assets that can yield an efficient portfolio. This insinuates that spreading of investments across divergent and unrelated pools minimizes exposures to the sudden, unforeseen outcome and in a diversified portfolio; gains from another investment subsequently offset a loss/risk in one investment. Thus, premising 
deductions on the outcome and study conclusions, the researcher recommends that the regulator also known as the apex bank (Central Bank of Kenya) should render close and regular supervision and keep track of deposit money banks' solidity and levels of liquidity in an endeavor to bring stability and financial health the banking industry of the economy and as well set a benchmark for their allocation of credit portfolio. Banks advances and loans should be intelligently collected and provision of defaults be ensured because it can never be avoided. Banks are obligated to have proper measures to lower risk through the process of portfolio management.

Funding: This research received no external funding.

Acknowledgments: The author acknowledges the scholarly support received from the School of Business, JKUAT.

Conflicts of Interest: The authors declare no conflict of interest.

\section{References}

Acharya, Viral V., Hasan, I., \& Saunders, A. (2006). Should Banks Be Diversified? Evidence from Individual Bank Loan Portfolios*. The Journal of Business, 79(3), 1355-1412. doi: 10.1086/500679

Afzal, A., \& Mirza, N. (2012). Size, diversification and risk: preliminary evidence from commercial banks in Pakistan. Pakistan Journal of Commerce and Social Sciences (PJCSS), 6(2), 282-296.

Al Karim, R., \& Alam, T. (2013). An evaluation of financial performance of private commercial banks in Bangladesh: Ratio analysis. Journal of Business Studies Quarterly, 5(2), 65.

Athanasoglou, P. P., Brissimis, S. N., \& Delis, M. D. (2008). Bank-specific, industry-specific and macroeconomic determinants of bank profitability. Journal of International Financial Markets, Institutions and Money, 18(2), 121-136. doi: 10.1016/j.intfin.2006.07.001

Berger, A. N., Hasan, I., Korhonen, I., \& Zhou, M. (2010). Does Diversification Increase or Decrease Bank Risk and Performance? Evidence on Diversification and the Risk-Return Tradeoff in Banking. SSRN Electronic Journal. doi: 10.2139/ssrn.1651131

Choi, I. (2001). Unit root tests for panel data. Journal of International Money and Finance, 20(2), 249-272. doi: 10.1016/S0261-5606(00)00048-6

Clarke, R., Davies, S., \& Waterson, M. (1984). The Profitability-Concentration Relation: Market Power or Efficiency? The Journal of Industrial Economics, 32(4), 435. doi: 10.2307/2098228

DeYoung, R., \& Rice, T. (2004). Noninterest Income and Financial Performance at U.S. Commercial Banks. Financial Review, 39(1), 101-127. doi: 10.1111/j.0732-8516.2004.00069.x

Ebrahim, A., \& Hasan, I. (2008). The value relevance of product diversification in commercial banks. Review of Accounting and Finance, 7(1), 24-37. doi: 10.1108/14757700810853833

Fama, E. F., \& French, K. R. (2005). Financing decisions: who issues stock? Journal of Financial Economics, 76(3), 549-582. doi: 10.1016/j.jfineco.2004.10.003

Hanafi Tumin, M., \& Mohd Said, R. (2010). Performance and Financial Ratios of Commercial Banks in Malaysia and China. SSRN Electronic Journal. doi: 10.2139/ssrn.1663612

Karray, S. C., \& Chichti, J. e. (2013). Bank size and efficiency in developing countries: intermediation approach versus value added approach and impact of non-traditional activities. Asian Economic and Financial Review, 3(5), 593.

Kazan, H., \& Uludag, K. (2014). Credit portfolio selection according to sectors in risky environments: Markowitz practice. Asian Economic and Financial Review, 4(9), 1208.

Kipleting, M. (2016). Effect of investment Diversification on the Financial performance of commercial banks in Kenya. IOSR Journal of Business and Management, 18(11), 102-115.

Kiyota, H. (2011). Efficiency of commercial banks in Sub-Saharan Africa: A comparative analysis of domestic and foreign banks: WIDER Working Paper. 
Landi, A., \& Venturelli, V. (2001). The Diversification Strategy of European Banks: Determinants and Effects on Efficiency and Profitability. SSRN Electronic Journal. doi: 10.2139/ssrn.269841

Lewellen, J. W., \& Lewellen, K. (2010). Investment and Cashflow. SSRN Electronic Journal. doi: $10.2139 /$ ssrn. 1570640

Markowitz, H. (1952). Portfolio Selection. The Journal of Finance, 7(1), 77. doi: 10.2307/2975974

Markowitz, H. (1959). Portfolio selection: Efficient diversification of investments (Vol. 16): John Wiley New York.

Meressa, H. A. (2017). An econometric analysis of the nexus between banks' sub-sectoral credit allocation and operating profit: Evidence from private commercial banks in Ethiopia. Developing country studies, 7(4), 3137.

Mulwa, J. M., Tarus, D., \& Kosgei, D. (2015). Commercial bank diversification: a theoretical survey. International Journal of Research in Management \& Business Studies, 2(1), 45-49.

Ndungu, J. G., \& Muturi, W. (2019). Effect of Diversification on Financial Performance of Commercial Banks in Kenya. International Journal of Current Aspects, 3(V), 267-285. doi: 10.35942/ijcab.v3iV.67

Nisar, S., Peng, K., Wang, S., \& Ashraf, B. (2018). The Impact of Revenue Diversification on Bank Profitability and Stability: Empirical Evidence from South Asian Countries. International Journal of Financial Studies, 6(2), 40. doi: 10.3390/ijfs6020040

Nodeh, F. M., Anuar, M. A., Ramakrishnan, S., \& Raftnia, A. A. (2015). The Effect of Board Structure on Banks Financial Performance by Moderating Firm Size. Mediterranean Journal of Social Sciences. doi: 10.5901/mjss.2016.v7n1p258

Olarewaju, O. M., Migiro, S. O., \& Sibanda, M. (2018). Dividend Payout, Retention Policy and Financial Performance in Commercial Banks: Any Causal Relationship? Studia Universitatis Babeș-Bolyai Oeconomica, 63(1), 37-62. doi: 10.2478/subboec-2018-0003

Pils, F. (2009). Meta-Analysis on the Relationship between Diversification and Performance Diversification, Relatedness, and Performance (pp. 9-61). Wiesbaden: Gabler.

Raphael, G. (2013). Efficiency of Commercial Banks in East Africa: A Non Parametric Approach. International Journal of Business and Management, 8(4), p50. doi: 10.5539/ijbm.v8n4p50

Stiroh, K. J. (2004). Do Community Banks Benefit from Diversification? Journal of Financial Services Research, 25(2/3), 135-160. doi: 10.1023/B:FINA.0000020657.59334.76

Turkmen, S. Y., \& Yigit, I. (2012). Diversification in banking and its effect on banks' performance: Evidence from Turkey. American international journal of contemporary research, 2(12), 111-119.

Verbeek, M. (2008). A guide to modern econometrics: John Wiley \& Sons. 